\title{
Genetic Diversity of the Pepper Pathogen Phytophthora capsici on Farms in the Amazonian High Jungle of Peru
}

\author{
Jon Hulvey ${ }^{1}$, Oscar Hurtado-Gonzalez ${ }^{3}$, Liliana Aragón-Caballero ${ }^{4}$, Daniel Gobena ${ }^{2}$, Dylan Storey ${ }^{2}$, \\ Ledare Finley ${ }^{5}$, Kurt Lamour ${ }^{5}$
}

\begin{abstract}
${ }^{1}$ Department of Plant, Soil, and Insect Sciences, University of Massachusetts, Amherst, USA; ${ }^{2}$ Genome Science and Technology Graduate Program, University of Tennessee, Knoxville, USA; ${ }^{3}$ Pioneer Hi-Bred International Inc., Johnston, USA; ${ }^{4}$ Department of Phytopathology, National Agrarian University-La Molina, Lima, Peru; ${ }^{5}$ Department of Entomology and Plant Pathology, University of Tennessee, Knoxville, USA.

Email:klamour@utk.edu
\end{abstract}

Received June $27^{\text {th }}, 2011$; revised July $7^{\text {th }}$, 2011; accepted July $15^{\text {th }}, 2011$.

\begin{abstract}
Phytophthora capsici is an important oomycete pathogen of Capsicum peppers worldwide. Populations of P. capsici recovered from coastal regions in Peru were previously shown to be dominated by a single clonal lineage referred to as PcPE-1. During 2008, 219 isolates of P. capsici were collected from Capsicum pubescens (Rocoto), C. annum (Pimento), and C. baccatum (Aji) at 9 farms in the Amazonian high jungle in the areas surrounding Oxapampa, and one coastal location, Carabayllo. Two isolates of P. capsici were also recovered from Cyclanthera pedata (Caigua fruit) near one field. All isolates were characterized using a panel of eight single nucleotide polymorphism (SNP) markers that are fixed for heterozygosity in the PCPE-1 lineage. A subset of isolates was also characterized using amplified fragment length polymorphism (AFLP) markers. Nine discreet SNP multi-locus genotypes were identified, and the $P C P E-1$ lineage was recovered from all of the field sites. Both A1 and A2 mating types were recovered from two sites. The implications of the genotypic diversity and distribution identified in this study are discussed.
\end{abstract}

Keywords: Population Genetics, DNA Markers, Clonality, Asexual Reproduction, Sexual Reproduction

\section{Introduction}

Phytophthora capsici is an important pathogen of vegetable crops such as tomato, pepper, cucumber and squash and more recently snap bean [1-3]. Infestations of Phytophthora capsici on annual crops typically require warm and wetter than average conditions, and can spread rapidly due to the production of asexually produced deciduous sporangia and motile zoospores [4]. In North America, sexual recombination and the production of the thick walled oospore is common and dormant oospores may persist in the soil for years. For North American populations, the combination of asexual and sexual reproduction affords $P$. capsici the benefits of both explosive clonal reproduction and the high genetic variation generated by sexual recombination [4]. Characterizing genotypic diversity plays an important role in determining whether the asexual or sexual portion of the Phytophthora life cycle is driving the epidemiology of the pathogen. A number of techniques have been utilized to assess genotypic diversity in Phytophthora (e.g. amplified fragment length polymorphism (AFLP), microsatellite (SSR), and isozyme markers) and more recently, single nucleotide polymorphisms (SNPs) have provided useful markers for characterizing field isolates [5-7].

The population structure of $P$. capsici from fields in the US includes considerable genotypic diversity, along with the presence of both mating types $[6,8,9]$. It appears that the winter (or fallow) season imposes an effective selection pressure favoring the oospore for survival of the pathogen. Populations of $P$. capsici from pepper fields in Peru display a much different genotypic makeup, with only three genotypes documented and a single clonal lineage of the A2 mating type (designated PcPE-1) dominating pepper and tomato fields in coastal Peru [10]. In some cases, cropping in the coastal area of Peru includes pepper production year round as well as irrigation from common river systems. In these areas, the irrigation strategy and the availability of host material may explain 
the widespread occurrence of PcPE-1, as surface waters have been shown to harbor abundant populations of $P$. capsici [11].

Our objective was to determine if epidemic populations of $P$. capsici from locations further inland across the Andes Mountains and into the Amazon rainforest harbored the PcPE-1 clonal A2 genotype, or if evidence of a more heterogeneous population structure characteristic of North American P. capsici populations could be detected.

\section{Materials and Methods}

\subsection{Collection and Culturing}

Isolates were collected from eleven pepper fields in Peru during May 2008. These include nine fields surrounding Oxapampa, Peru, one field in Azucazu, just north of Oxapampa, and one field located on the coast in Carabayllo (Figure 1). The nine fields surrounding Oxapampa span a total of approximately $200 \mathrm{~km}^{2}$, and all fields in total span a distance of $400 \mathrm{~km}$, from Azucazu to Carabayello. Isolates were obtained by plating small sections of infected fruit, crown, or root material of Capsicum spp. on V8-PARP agar medium (40 $\mathrm{ml} \mathrm{V8} \mathrm{juice,} 3$ $\mathrm{g} \mathrm{CaCO}_{3}, 16 \mathrm{~g}$ Bacto agar and $960 \mathrm{ml}$ water amended with $25 \mathrm{ppm}$ pimaricin, $100 \mathrm{ppm}$ ampicillin, $25 \mathrm{ppm}$ rifampicin, and $25 \mathrm{ppm}$ pentachloronitrobenzene). Plates were observed daily and single hyphal tips recovered from expanding colonies. A single isolate was recovered per plant and used in the subsequent analyses.

\subsection{Mating Type and DNA Extraction}

Mating type determination was accomplished using $P$. capsici A1 and A2 tester isolates (CBS121656 and CBS121657, respectively). Seven millimeter agar discs from the leading edge of colonies of tester and query isolates were plated together onto dilute V8-PARP plates. After 7 to 14 days, the colony intersection was excised, slide mounted and observed microscopically. The presence or absence of oospores was then determined by light microscopy observation at $400 \mathrm{X}$ magnification. DNA was produced by 1) growing mycelium in V8 PARP broth for 7 days; 2) lyophilizing the harvested mycelium; and 3) extracting high molecular weight DNA from the pulverized dried mycelium according to the methods outlined previously [12].

\subsection{SNP Genotyping Using DNA Melting Analysis}

Eight high resolution DNA melting analysis (HR-DMA) assays were optimized to resolve SNP genotypes at loci heterozygous within single genes of the PcPE-1 clonal lineage. The assays were designed to differentiate ho- mozygote and heterozygote alleles. Marker loci were chosen from an expressed sequence tag (EST) library of the $P$. capsici genome, and these genes were re-sequenced in a PcPE-1 representative isolate (LT2135). A single heterozygous SNP was targeted from each of the eight genes. Primers were designed using the LightScanner primer design software (Idaho Technologies, Salt Lake City, UT) to amplify a 45 - 65 bp amplicon that spanned a single heterozygous site (See Table 1 for primer sequences). PCR reactions for DMA consisted of $4 \mu \mathrm{l}$ Lightscanner Mastermix (Idaho Technologies, Salt Lake City, UT), $1 \mu$ l of genomic DNA at 10 to $20 \mathrm{ng} / \mu \mathrm{l}$, and $1 \mu \mathrm{l}$ of each primer at $2.5 \mu \mathrm{M}$ conc. The PCR temperature protocol was as follows: initial denaturation at $95 \mathrm{C}$ for $2 \mathrm{~min}$, then 45 cycles of $95 \mathrm{C}$ for $30 \mathrm{~s}$ and $64 \mathrm{C}$ for $30 \mathrm{~s}$, and then a final step of $95 \mathrm{C}$ for $30 \mathrm{~s}$ followed by $28 \mathrm{C}$ for $30 \mathrm{~s}$. HR-DMA was performed according to manufacturer's instructions using a 384 well format Lightscanner instrument (Idaho Technologies, Salt Lake City, UT). All assays were repeated to ensure reproducibility. Data analysis and normality parameters were adjusted using LightScanner 2.0 software. DNA sequencing of an isolate representing each of the DMA melt curve types was performed to confirm genotypes. Known isolates of the PcPE-1 clonal lineage were included in all assays to detect the presence of the clonal lineage.

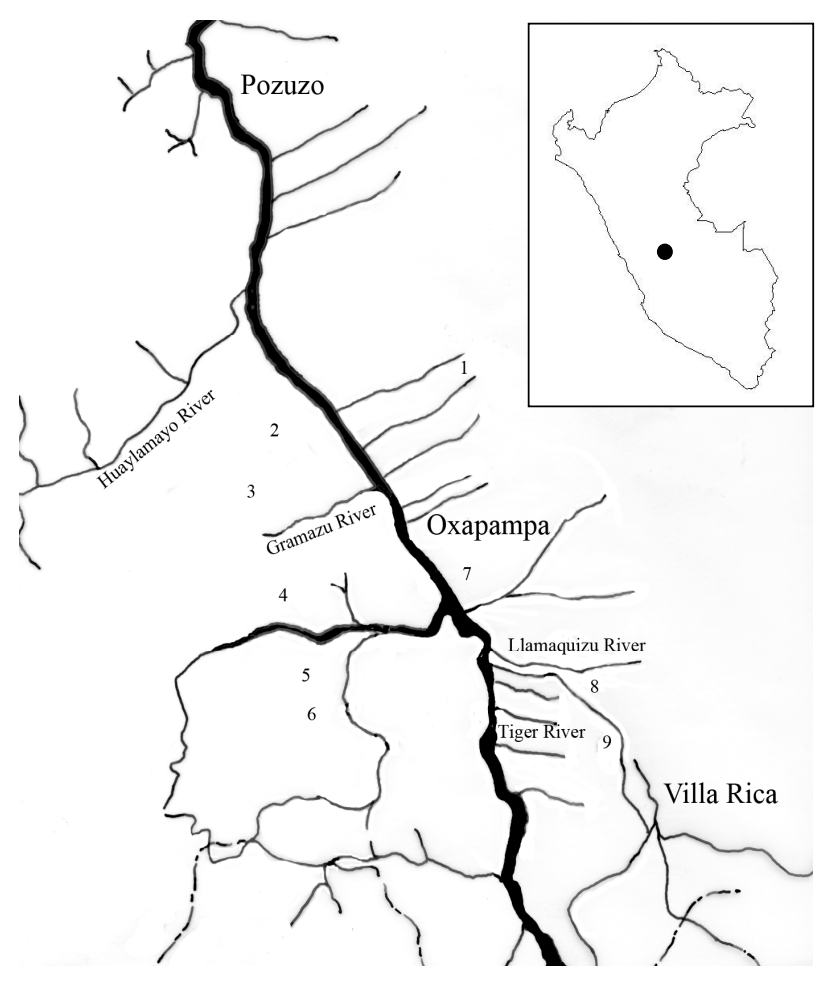

Figure 1. Map of collection sites surrounding Oxapampa. Sites are numbered 1 through 9. Inset is Peru map, with Oxapampa marked with a black dot. 
Table 1. Summary information for high resolution DNA melting analysis markers.

\begin{tabular}{|c|c|c|c|c|}
\hline Locus ID $^{\mathrm{a}}$ & Genbank accession & Base pair of SNP ${ }^{b}$ & SNP & Forward Primer/Reverse Primer \\
\hline Flc3 & ВTO32098 & 2010 & $\mathrm{~T} / \mathrm{C}$ & $\begin{array}{l}\text { GCCCAAGTAGCAAAGCTCA/ } \\
\text { GTCCACAGCGATGGTCT }\end{array}$ \\
\hline Flc12 & BTO31712 & 2137 & $\mathrm{C} / \mathrm{T}$ & $\begin{array}{l}\text { TATCCTCCACGTACTCGAAG/ } \\
\text { AGGTTGCTCAGGTGATG }\end{array}$ \\
\hline Flc18 & BTO32197 & 3395 & $\mathrm{~T} / \mathrm{C}$ & $\begin{array}{l}\text { GCACCTCTTCTGTGCAG/ } \\
\text { GTCGTCTGGTCTTCACTTG }\end{array}$ \\
\hline Flc19 & BTO31656 & 2831 & $\mathrm{C} / \mathrm{T}$ & $\begin{array}{l}\text { CATCATGCACCATGAGTTTG/ } \\
\text { CCTTCTTACCGTCTTCGT }\end{array}$ \\
\hline Flc23 & BTO31999 & 1048 & $\mathrm{C} / \mathrm{T}$ & $\begin{array}{l}\text { TCTGACGATGCTGTCCC/ } \\
\text { TTCGTTCCTTAACGCCG }\end{array}$ \\
\hline Flc24 & BTO32352 & 989 & $\mathrm{C} / \mathrm{T}$ & $\begin{array}{l}\text { ATCCTGGACATGGACCC/ } \\
\text { CAGGTACAGGTGCCTCA }\end{array}$ \\
\hline Flc29 & BTO31539 & 684 & $\mathrm{C} / \mathrm{A}$ & $\begin{array}{l}\text { AATGACCCGAACGAAGT/ } \\
\text { GAAATAGCTGAAGAAATGCTCC }\end{array}$ \\
\hline Flc34 & BTO31610 & 1773 & $\mathrm{G} / \mathrm{T}$ & $\begin{array}{l}\text { CGCCCCTGTATCAGAAG/ } \\
\text { CACGCGTCCTTGCTTAC }\end{array}$ \\
\hline
\end{tabular}

${ }^{\mathrm{a}}$ Informal locus identifiers; ${ }^{\mathrm{b}}$ Base pair number of polymorphic site from the 5 ' end of the Genbank sequence.

\subsection{AFLP Analyses}

Amplified Fragment Length Polymorphism (AFLP) analysis was performed using Eco RI, and MseI restriction enzymes, adapters, and polymerase chain reaction (PCR) amplification primers following the method of [13]. Selective PCR amplifications were performed with Eco-CG and Mse-CG primer pairs. Amplicons were fluorescently labeled in separate reactions following the method of [14], and the resultant fluorescently labeled amplicons were resolved by a Beckman-Coulter CEQ8000 capillary genetic analysis instrument. Fragment peaks were manually confirmed, and peaks between 100 and 600 base pairs in size were manually scored for presence or absence.

\section{Results}

A total of 219 isolates were recovered from infected plants at the eleven locations sampled (Figure 1, Table 2). Isolates of A2 mating type were recovered from all fields.
Table 2. Isolate summary information.

\begin{tabular}{|c|c|c|c|}
\hline Location $^{\mathrm{a}}$ & Hosts & No. isolates & Mating Type \\
\hline Field $1 *$ & C. pubescens & 60 & A2 \\
\hline Field 2 & $\begin{array}{l}\text { C. pubescens } \\
\text { C. baccatum }\end{array}$ & 18 & A2 (8), A1 (10) \\
\hline Field 3 & $\begin{array}{l}\text { C. pubescens, } \\
\text { C. baccatum }\end{array}$ & 12 & $\mathrm{~A} 2(6), \mathrm{A} 1$ (6) \\
\hline Field $4 *$ & C. baccatum & 7 & A2 \\
\hline Field $5^{*}$ & C. pubescens & 2 & A2 \\
\hline Field $6^{*}$ & C. pubescens & 2 & A2 \\
\hline Field $7 *$ & C. pubescens & 33 & A2 \\
\hline Field 8 & C. pubescens & 1 & $\mathrm{~A} 2$ \\
\hline Field $9 *$ & $\begin{array}{c}\text { C. pubescens, } \\
\text { Cyclanthera pedata }\end{array}$ & 66 & A2 \\
\hline Acuzazu & C. pubescens & 8 & $\mathrm{~A} 2$ \\
\hline Carabayllo & C. annum & 14 & $\mathrm{~A} 2$ \\
\hline
\end{tabular}

${ }^{\mathrm{a}}$ All isolates were of the PcPE-1 genotype. 
Seven percent of the isolates were of the A1 mating type, originating from only two fields (Table 2). The majority of isolates (166) were recovered from rocoto (Figure 2), with fewer isolates from Aji (37), Pimento (14), and Caigua (2) (Table 2). The isolates were found to comprise nine genotypes based on the multi-locus SNP genotyping (Tables 3 and 4). These included the genotypes PcPE-1, PcPE-2, and PcPE-3 previously identified from samples recovered at more coastal locations (e.g. west of the Andes Mountains) [10] (Tables 3, 4). AFLP fingerprinting resulted in the identification of 50 informative bands. All 48 of the isolates analyzed using AFLP had identical PcPE-1 genotypes and the SNP typing confirmed that all isolates were fixed for heterozygosity at all 8 loci assayed. The PcPE-1 genotype was recovered from all eleven fields, and comprised $75 \%$ of all isolates collected, whereas, isolates of the remaining eight additional genotypes each comprised less than $10 \%$ of the total isolates (Table 3).

\section{Discussion}

Our objective was to determine if the PcPE-1 clonal lineage was also present at sites on the eastern side of the Andes Mountains where peppers (primarily "rocoto", $C$. pubescens) are often grown on smaller plots. Samples were collected in March of 2008 shortly after the rainy season ended. The plants had mature fruit and the pepper harvest was ongoing. Although isolates of $P$. capsici were recovered from C. baccatum, C. annum, and what is known as the wild cucumber (Cyclanthera pedata), most of the isolates were recovered from infected fruit of rocoto. The rocoto fruit has a thick waxy cuticle which becomes detached during the infection process, and is referred to as the "pealing pealing" disease in the areas around Oxapampa (Figure 2).
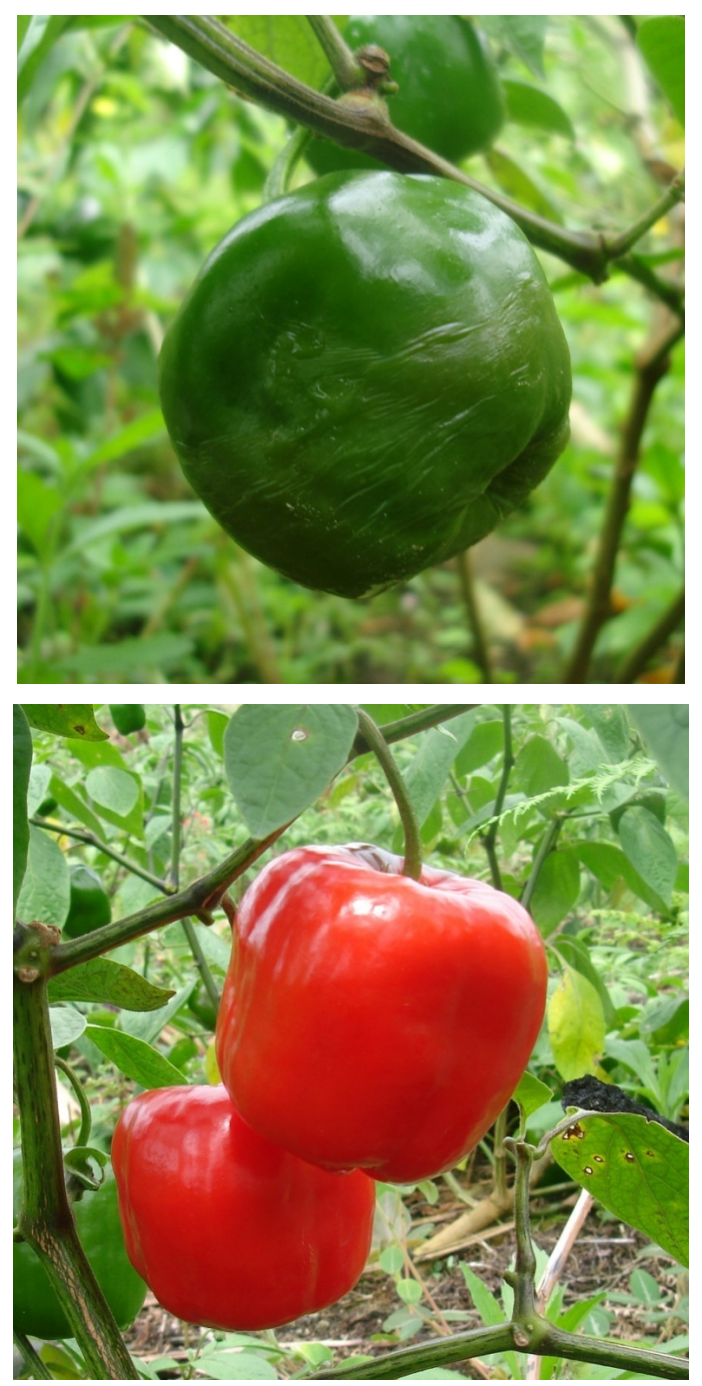

Figure 2. (Top) Rocoto fruit infected with Phytophthora capsici and (Bottom) Healthy Rocoto fruit.

Table 3. Summary of the distribution of Phytophthora capsici genotypes.

\begin{tabular}{ccccc}
\hline Genotype & Mating Type & Host(s) & Locations & Number of isolates (percent of total) \\
\hline PcPE-1 & A2 & $\begin{array}{c}\text { C. pubescens, C. annum, } \\
\text { C. baccatum, Cyclanthera } 5 p .\end{array}$ & 1-7, Azucazu, Carabayllo & $134(61)$ \\
PcPE-2 & A2 & C. pubescens & 1 & $9(4)$ \\
PcPE-3 & A2 & C. pubescens & 7 & $20(9)$ \\
PcPE-4 & A2 & C. pubescens & $3,7,9$ & $2(1)$ \\
PcPE-5 & A2 & C. pubescens, C. baccatum & 9 & $18(8)$ \\
PcPE-6 & A2 & C. pubescens, C. baccatum & 9 & $7(3)$ \\
PcPE-7 & A2 & C. pubescens, C. baccatum & 9 & $10(5)$ \\
PcPE-8 & A1 & C. pubescens & 2,3 & $7(3)$ \\
PcPE-9 & A1 & C. pubescens & 2,3 & \\
\hline
\end{tabular}


Table 4. Summary of SNP genotypes for nine clonal lineages of Phytophthora capsici recovered from Peru.

\begin{tabular}{ccccccccc}
\hline Genotype & FL3 ${ }^{\mathrm{a}}$ & FL12 & FL18 & FL19 & FL23 & FL24 & FL29 & FL34 \\
\hline PcPE-1 & G/A & C/T & A/C & G/A & G/A & C/T & G/T & A/C \\
PcPE-2 & A/A & C/T & A/C & G/A & G/A & C/T & G/T & A/C \\
PcPE-3 & G/A & C/T & A/C & G/A & G/A & C/C & G/G & A/C \\
PcPE-4 & G/A & C/T & A/C & G/G & G/A & C/C & G/G & A/C \\
PcPE-5 & G/A & C/T & C/C & G/A & A/A & C/C & G/G & A/C \\
PcPE-6 & G/A & C/T & C/C & G/A & G/G & C/C & G/G & A/C \\
PcPE-7 & G/A & C/T & C/C & G/A & G/G & C/C & G/G & A/A \\
PcPE-8 & A/A & C/C & A/C & G/G & G/A & C/C & G/T & A/A \\
PcPE-9 & G/G & C/C & A/C & G/G & G/A & C/C & G/T & A/A \\
\hline
\end{tabular}

${ }^{\text {a }}$ Marker details are listed in Table 1.

In contrast to some of the areas sampled along the coast (e.g. along the Supe River), none of the sites were irrigated by a common river source. All of the sites were located at relatively steep areas of the cloud forest where the forest and undergrowth had been cut and burned or manually cleared. The farmers indicated that individual rocoto plants had often been productive for up to 5 years prior to an increase of the "pealing pealing" disease over the past 3 to 4 years. The current strategy to combat the disease is to clear new forest every 1 to 2 years due to an increase in the prevalence of the disease. Our results indicate that the PcPE-1 clonal genotype is a prevalent member of the population structure of $P$. capsici in the areas surrounding Oxapampa. The PcPE-1 lineage was recovered from all of the hosts sampled and was present at every location. Although PcPE-1 is the most frequent, interestingly, we also recovered two clonal lineages of the A1 mating type (PcPE-8 and PcPE-9) which were present at two different locations. Tests are underway to determine the fecundity of crosses between these A1 lineages and the dominant PcPE-1 lineage. Preliminary observations indicate that crosses produce normally formed oospores but recovery of progeny and genotypes has yet to be attempted.

Clearly clonal reproduction is driving population structures in the areas surrounding Oxapampa. Due to the limited number of unique genotypes it is difficult to assess the importance of sexual recombination-although the allelic combinations resolved via the SNP typing indicate that sexual recombination may have played a role in generating at least some of the observed genotypic variation. Similar to some of the coastal areas where pepper is produced, there is susceptible host material (pepper and caigua) throughout the year and there is likely limited selection pressure working against the survival and spread of clonal lineages. How the PcPE-1 lineage has become so widespread is difficult to assess as there is very little genotypic diversity. It may be that a single clonal lineage has been dispersed throughout Peru by the exchange of infected plant material or seed, as is seen with many economically important Phytophthora pathogens, such as $P$. ramorum, $P$. infestans, and other oomycete pathogens [15-17].

Although the genotypic diversity was higher in this region than the coastal areas, it is still much lower than findings for $P$. capsici in North America $[6,9,18]$. The PcPE-1 genotype was also isolated from Cyclanthera pedata in the nearby cloud forest of one field, indicating this host may be an important reservoir for $P$. capsici in the surrounding Amazon. This is not surprising as Phytophthora capsici has also been reported to infect weedy plants such as American black nightshade and Purslane in the US near vegetable farms [19]. The finding of limited genotypic diversity throughout Peru indicates that the strategic deployment of tolerant or resistant pepper germplasm may be effective in reducing the overall significance of this important disease.

\section{REFERENCES}

[1] A. J. Gevens, R. S. Donahoo, K. H. Lamour and M. K. Hausbeck, "Characterization of Phytophthora capsici Causing Foliar and Pod Blight of Snap Bean in Michigan," Plant Disease, Vol. 92, No. 2, 2008, pp. 201-209. doi:10.1094/PDIS-92-2-0201

[2] C. R. Davidson, R. B. Carroll, T. A. Evans, R. P. Mulrooney and S. H. Kim, "First Report of Phytophthora capsici Infecting Lima Bean (Phaseolus lunatus) in the Mid-Atlantic Region," Plant Disease, Vol. 86, No. 9, 2002, pp. 1049-1049. doi:10.1094/PDIS.2002.86.9.1049A 
[3] D. C. Erwin and O. K. Ribeiro, "Phytophthora Diseases Worldwide,” APS Press, St. Paul, 1996.

[4] K. Lamour and S. Kamoun, "Oomycete Genetics and Genomics: Diversity, Interactions, and Research Tools," Wiley-Blackwell, Hoboken, 2009.

[5] D. P. Garnica, A. M. Pinzon, L. M. Quesada-Ocampo, A. J. Bernal, E. Barreto, N. J. Grunwald and S. Restrepo, "Survey and Analysis of Microsatellites from Transcript Sequences in Phytophthora Species: Frequency, Distribution, and Potential as Markers for the Genus," BMC Genomics, Vol. 7, 2006, p. 245. doi:10.1186/1471-2164-7-245

[6] A. R. Dunn, M. G. Milgroom, J. C. Meitz, A. McLeod, W. E. Fry, M. T. McGrath, H. R. Dillard and C. D. Smart, "Population Structure and Resistance to Mefenoxam of Phytophthora capsici in New York State," Plant Disease, Vol. 94, No. 12, 2010, pp. 1461-1468. doi:10.1094/PDIS-03-10-0221

[7] F. Niepold, "Application of the SNP-Analysis for Characterization of Phytophthora infestans Isolates," Nachrichtenblatt des Deutschen Pflanzenschutzdienstes, Vol. 57, No. 9, 2005, pp. 183-187.

[8] K. H. Lamour and M. K. Hausbeck, "Investigating the Spatiotemporal Genetic Structure of Phytophthora capsici in Michigan," Phytopathology, Vol. 91, No. 10, 2001, pp. 973-980.

[9] K. H. Lamour and M. K. Hausbeck, "The Dynamics of Mefenoxam Insensitivity in a Recombining Population of Phytophthora capsici Characterized with Amplified Fragment Length Polymorphism Markers," Phytopathology, Vol. 91, No. 6, 2001, pp. 553-557.

[10] O. Hurtado-Gonzales, L. Aragon-Caballero, W. ApazaTapia, R. Donahoo and K. Lamour, "Survival and Spread of Phytophthora capsici in Coastal Peru," Phytopathology, Vol. 98, No. 6, 2008, pp. 688-694.

[11] A. J. Gevens, R. S. Donahoo, K. H. Lamour and M. K. Hausbeck, "Characterization of Phytophthora capsici from
Michigan Surface Irrigation Water," Phytopathology, Vol. 97, No. 4, 2007, pp. 421-428.

[12] K. Lamour and L. Finley, "A Strategy for Recovering High Quality Genomic DNA from a Large Number of Phytophthora Isolates," Mycologia, Vol. 98, No. 3, 2006, pp. 514-517.

[13] P. Vos, R. Hogers, M. Bleeker, M. Reijans, T. Vandelee, M. Hornes, A. Frijters, J. Pot, J. Peleman, M. Kuiper and M. Zabeau, "AFLP: A New Technique for DNA-Fingerprinting," Nucleic Acids Research, Vol. 23, No. 21, 1995, pp. 4407-4414. doi:10.1093/nar/23.21.4407

[14] L. Habera, N. Smith, R. Donahoo and K. Lamour, "Use of a Single Primer to Fluorescently Label Selective Amplified Fragment Length Polymorphism Reactions," Biotechniques, Vol. 37, No. 6, 2004, pp. 902-904.

[15] W. E. Fry, S. B. Goodwin, A. T. Dyer, J. M. Matuszak, A. Drenth, P. W. Tooley, L. S. Sujkowski, Y. J. Koh, B. A. Cohen, L. J. Spielman, K. L. Deahl, D. A. Inglis and K. P. Sandlan, "Historical and Recent Migrations of Phytophthora infestans: Chronology, Pathways, and Implications," Plant Disease, Vol. 77, No. 7, 1993, pp. 653-661. doi:10.1094/PD-77-0653

[16] E. Stokstad, "Nurseries May Have Shipped Sudden Oak Death Pathogen Nationwide," Science, Vol. 303, No. 5666, 2004, p. 1959.

[17] E. Hansen, "Alien Forest Pathogens: Phytophthora Species Are Changing the World Forests," Boreal Environment Research, Vol. 13, 2008, pp. 33-41.

[18] K. H. Lamour and M. K. Hausbeck, "The Spatiotemporal Genetic Structure of Phytophthora capsici in Michigan and Implications for Disease Management," Phytopathology, Vol. 92, No. 6, 2002, pp. 681-684.

[19] R. D. French-Monar, J. B. Jones and P. D. Roberts, "Characterization of Phytophthora capsici Associated with Roots of Weeds on Florida Vegetable Farms," Plant Disease, Vol. 90, No. 3, 2006, pp. 345-350. doi:10.1094/PD-90-0345 